\title{
Lady Mary Wroth's Pamphilia to Amphilanthus: The Politics of Withdrawal
}

\author{
Rosalind Smith
}

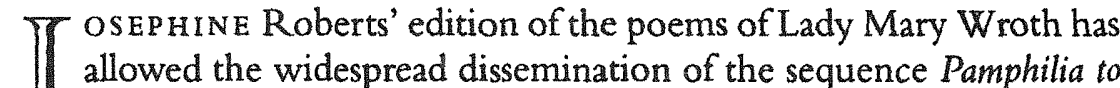
a Amphilanthus, and has been instrumental in establishing Wroth as a primary example of the Renaissance woman poet. Coupled with the text of Wroth's poems is Roberts' history of the text's reception, a narrative of women's limited textual agency and constraint in the public sphere. ${ }^{1}$ Roberts' introduction provides evidence for the Urania's status as a roman à clef, and indicates that one episode, outlining the violent and coercive behavior of the characters of Seralius and his father-in-law, was read by Edward Denny as an attack upon himself and his family. Denny responded with two letters and a poem of revenge, "To Pamphilia from the father-in-law of Seralius," which begins by accusing Wroth of being a "Hermophradite in show," and concludes by encouraging women's textual silence and confinement to religious activity: "Work o th' Workes leave idle bookes alone / For wise and worthyer women have writte none" (pp. 32-33). Roberts records a poem written by Wroth in response that rebuffs Denny's intimidation but emphasizes his use of discourses of gender in his attack upon her by quoting from his letters a section recommending that Wroth "redeem the time with writing as large a volume of heavenly lays and holy love as you have of lascivious tales and amorous toys; that at the last you may follow the example of your virtuous and learned aunt." As a part of her response to Denny, Roberts reports, Wroth "even wrote to the Duke of Buckingham" defending her innocence, claiming to have stopped the sale of the text, and seeking his aid in recovering the copies of Urania which had already been sold. The Urania was entered in the Stationers' Register on July 13, I62 I; by De-

1. The Poems of Lady Mary Wroth, ed. Josephine Roberts (Baton Rouge, 1983), pp. $31-35$. 


\section{Rosalind Smith}

cember 1621 , as her letter to Buckingham indicates, Wroth claimed she was attempting to withdraw the Urania from sale. Roberts' construction of the exchange positions Wroth in the role of a brave but powerless victim - "Despite Lady Mary Wroth's show of courage, she was obliged to send letters to her friends for help"-forced by Denny's deployment of restrictive discourses of gender to withdraw her text from sale (p. 3s).

This emphasis on Wroth's lack of agency consistently shapes readings of the publication history of the text in later criticism. Elizabeth Hanson, Kim Walker and Elaine Beilin repeat Roberts' narrative of scandal and withdrawal; Walker and Beilin cite the same passages as Roberts selects in her introduction from Denny's letters that suggest Wroth follow the generic example of her aunt, the Countess of Pembroke. ${ }^{2}$ Jeff Masten sees the same themes of gender-specific attack and withdrawal as characteristic of the Urania's circulation history and as illustrations of a theory of Renaissance women's subjectivity, linking Wroth's staged withdrawal of her texts from circulation with Pamphilia's withdrawal into interiority in the sonnets: "In writing to Buckingham, Wroth stages anxieties of publication in comparable spatial metaphors; the offending books-like Pamphilia herself in the sonnets and romance-she promises to 'shut up' and 'gett in." 3 In Wendy Wall's version of the Roberts' narrative Wroth's publication of the Urania "met with scandal when Lord Edward Denny accused her of libel and demanded that the text be withdrawn," not only because of the text's topical allusions but as part of an attack on "female authorship in general." 4 Gary Waller's reading does not maintain that Denny demanded the text to be withdrawn, but does agree with Roberts that Denny's deployment of discourses surrounding gender and genre led to the text's suppression. ${ }^{5}$ Maureen Quilligan argues that "real political risks" ensued from Wroth's deviation from Mary Sidney's exam-

2. Kim Walker, Women Writers of the English Renaissance (New York, 1996), pp. 175-76; Elaine Beilin, Redeeming Eve: Women Writers of the English Renaissance (Princeton, 1987), p. 21 ; Elizabeth Hanson, "Boredom and Whoredom: Reading Renaissance Women's Sonnet Sequences," Yale Journal of Criticism 10:1 (1997), 178-79.

3. Jeff Masten, “'Shall I turne blabb?': Circulation, Gender, and Subjectivity in Mary Wroth's Sonnets," in Reading Mary Wroth: Representing Alternatives in Early Modern England, ed. Naomi J. Miller and Gary Waller (Knoxville, 1991), p. 84.

4. Wendy Wall, The Imprint of Gender: Authorship and Publication in the English Renaissance (Ithaca, 1993), p. 337.

S. Gary Waller, The Sidney Family Romance: Mary Wroth, William Herbert, and the Early Modern Construction of Gender (Detroit, 1993), pp. 109, 129-30. Although Waller's first reference to the scandal typically cites Denny's exhortations that Wroth "follow the lead of her aunt" in writing devotional texts and reads his hostility as a response to an act of "sexual defiance," Waller's later discussion is careful to incorporate some of Wroth's response to Denny, and interprets her letter to Buckingham in less causal terms as an expression of fear of official action (pp. 129-30). 
ple, but notes, as does Barbara Lewalski, that there is no evidence for the text's suppression. ${ }^{6}$ Despite these caveats, the story of the Urania's genderdriven suppression has been generally available to represent an early modern "taboo against the publication of women," allowing Ellen Moody to conclude her article on the Anne Cecil de Vere sonnets by suggesting that the Urania and Pandora shared a similar publication history. Moody cites Wroth's letter to the Duke of Buckingham as an example of "the response-one of humiliation and desperation-of a nearly contemporary woman sonneteer and the kinds of steps she was personally prepared to take to hunt out and destroy her work."

Before the appearance of Roberts' edition of Wroth's poems and her discovery of the Denny correspondence, critics presented a different narrative of the Urania's contemporary reception, one with fewer direct links between discourses urging women's silence or textual confinement to religious writings and Wroth's withdrawal of the Urania from sale. Both May Paulissen and Bridget McCarthy cite a letter from John Chamberlain to Dudley Carleton on May 9, I623, almost two years after the Urania's first publication, reporting Denny's anger in response to the text. ${ }^{8}$ The date of this report suggests that Wroth's efforts to withdraw the text from sale might pre-date Denny's letters of attack, which a reexamination of the exchange of letters between Denny and Wroth confirms. Contrary to Roberts' linear narrative, which proposes that Denny's poem and letters prompted Wroth's letter to Buckingham withdrawing the text, the exchange of letters between Denny and Wroth began exactly two months after Wroth informed Buckingham of her efforts to withdraw the text from sale. Wroth's letter to Buckingham is dated December IS, I62I, and her first letter to Denny is dated February I 5 , I62 I / 2. There Wroth specifically states that Denny's verses have come to her attention only recently: "This day came to my handes some verses under the name of the Lord Denny's." Although it is possible that the

6. Maureen Quilligan, "The Constant Subject: Instability and Female Authority in Wroth's Urania Poems," in Soliciting Interpretation: Literary Theory and Seventeenth-Century English Poetry, ed. Elizabeth D. Harvey and Katharine Eisaman Maus (Chicago, 1990), p. 308; Barbara Lewalski, Writing Women in Jacobean England (Cambridge, Mass., 1993), p. 249.

7. Ellen Moody, "Six Elegaic Poems, Possibly by Anne Cecil de Vere, Countess of Oxford," English Literary Renaissance 19:2 (1989), 164 .

8. May Nelson Paulissen, The Love Sonnets of Lady Mary Wroth: A Critical Introduction (Salzburg, 1982), pp. 29-30; B.G. MacCarthy, Women Writers: Their Contribution to the English Novel, 16a11744 (Cork, 1944), pp. 62-63.

9. It is possible that Josephine Roberts has constructed these events as a narrative because Wroth has used the old style of dates, which would mean that Denny responded to the text in February 
reference to "this day" is rhetorical, and Denny's response to the Seralius episode was one of the "strang constructions" which Wroth claims motivated her withdrawal of the text in her letter to Buckingham, the causal connection between the narrative exchange between Wroth and Denny and the withdrawal of the text from sale is much less certain than Roberts' narrative of these events suggests.

What then may be made of Wroth's letter to Buckingham, written two months before Denny's identification of the text as scandalous? Taken at face value, it is politically expedient, concerned not "to give the least cause of offence" in the face of the "strang constructions" placed upon the text. However, Wroth's protestations of innocence are problematic in the face of her text's generic status as roman à clef, following the model provided by Argenis, a genre which had as its defining feature encoded references to specific individuals and events which, inevitably, were not uniformly complimentary. It seems more likely that Wroth's professed desire not to cause offense and to withdraw the text from sale, directed to Buckingham, a locus of significant power within the court, is an insurance policy, amounting to preemptively enlisting the protection of the favorite of the king. Wroth's rhetorical disassociation from the text allows her to position herself officially as innocent of both offense and a desire for publication, while still allowing the text to circulate. ${ }^{10}$ Contrary to the assumption generated by Roberts' narrative and reproduced by later critics, no evidence exists to suggest that Wroth's letter to Buckingham seeking the text's withdrawal from sale resulted in the text's suppression. There is no record of James I's issue of a warrant to that effect and no further reference in any of the subsequent correspondence concerning the text to Wroth's efforts to recall it; she later writes a substantial continuation in manuscript. The text's suppression itself is therefore as uncertain as the gender-driven cause of that suppression.

1621 , prompting Wroth to write to the Duke of Buckingham nine months later withdrawing the text from sale. Given the heated and rapid nature of their exchange, however, such a delay seems unlikely. There are several problems with this theory, not the least of which is Roberts' consistent use of dates in the new style in her text-she signals no shift to the old style of dates with reference to the correspondence between Denny and Wroth. It would also mean that Denny had access to a manuscript copy of the Urania five months before its publication, unlikely because of its size and Wroth's use of a printed copy as a presentation copy to the Duke of Buckingham, suggesting that she circulated the printed text in pre-existent systems of manuscript exchange.

10. Barbara Lewalski also argues that "the letter reads more like a conventional pro forma disclaimer to avoid trouble than like true angst: Wroth indicates with some pride that she expects real difficulty in getting people to relinquish their copies, and asks Buckingham to set a good example by returning the presentation copy she sent to him. Pretty clearly she expected (and expects) him to enjoy the work" (p. 249). 
The critical narrative of gender-repression also largely discounts Wroth's textual response to Denny's attack, because it problematizes any neat account of the suppression of the woman's voice. ${ }^{11}$ In Roberts' account Wroth sends Denny a poem imitating his, in which she takes the model of male rationality in the same way as Denny takes the model of female chastity, and there finds a monstrous confusion of gender, with Denny as a "Hirmophradite in sense" (p. 34). Nor is a narrative of silence suggested by Wroth's deployment of the materials of their correspondence. Her first letter to Lord Denny, accompanied by her answering poem, carries with it an implicit threat to circulate their letters and poems in her defense: "I send your Lordship your owne lines, (as they were called to mee) reversed; and the first coppyi; as desiring your owne eyes should bee first witnesse of your reward for your poetrie, if it were yours. This is the course I take yet; although your Lordship certainlie knowes, I may take others; and am not by this barred from anie" (p. 237). The reference to the "first" copy implies that others may be circulated if the later threat of other courses of action were not sufficient.

Denny's letter of response indicates how seriously he took Wroth's threat of circulation, and what such a threat meant in playing for the stakes of royal favor. His letter includes in his defense two panegyric references to James I, first as a "Wise King and Prince," and secondly as the reason for his self-defense-fear that her letters characterized him "as a scorn to the eyes of my dread and dear soveraigne and master" (pp. 238-39). Given Wroth's threat of circulation, these seem to be self-protective strategies should the correspondence reach the King. Wroth's later letter to Sir William Feilding, Earl of Denbigh, puts her threat into action, sending a set of documents to him in order that his "favor may make all well with his Majestie": "I presume to send thes things unto you, unfitt for your most judisiall eyes to beehold, and goodnes to read; and unseemly for mee to pubblish if innocensy guarded mee nott, butt cleerness in some part as never meant $\langle$ to $\rangle$ him, and faulshood on his syde in his accusation concerning drink, makes mee 〈willyngly > cast my self upon the same Jury hee taulks of, and from thence humbly to beeseech right, I can nott merritt any such favor butt by Loyallty, and truth, which may, and shall speake justly for mee, your favor may make all well with his Majestie."12

Denny's reference to Mary Sidney as an admonitory example of deco-

I I. Again, Maureen Quilligan's account is an exception to this, noting that Wroth sends her answering poem to Denny and to friends who might intercede on her behalf $(p .308)$.

12. Roberts, p. 242. The references to drunkenness and "the same Jury hee taulks of" indicates that the accompanying documents are copies of their correspondence. 


\section{Rosalind Smith}

rous textual activity for a woman, the only quotation from Denny's letters included in Roberts' introduction, occurs at the end of Denny's first letter to Wroth. Although used by Denny as one weapon among others in his attack upon Wroth, the example of Mary Sidney was insufficient to deter Wroth from circulating the letter as part of her defense. Rather than the final and oppressive statement of the correspondence, as Roberts implies, the example was only a skirmish in an attack vigorously answered by Wroth and taken by her from the level of private correspondence to wider circles of manuscript circulation.

The narrative of the text's withdrawal has fed into critical approaches toward both the prose romance and the sonnet sequence. It has influenced criticism of Pamphilia to Amphilanthus, most notably in Masten's influential essay, connecting Wroth's withdrawal of the text from sale and Pamphilia's withdrawal of her body from the systems of homosocial male traffic in women that underpin the construction of the traditional male Petrarchan subject (p. 84). This refusal to circulate delineates an alternative space for the construction of a nascent female subjectivity, a space characterized by its interiority and privacy. Both Gary Waller and Wendy Wall cite Masten's account as a gloss upon their own analyses. Wall celebrates that "the reader of her text has the rare opportunity to hear the silent mistress of the sonnet sequences finally speak," but she constructs women's position as speaker in such a way that it amounts to the secondary and imitative relation of transvestitism, "generically cross dressing as a male sonneteer." In Wall's terms that sonnet speaker, even in the brief moment of her articulation, "self-consciously meditates on the dilemma of what cannot be said," taking as her theme the restrictions of poetic discourse that are played out in Wall's version of the text's reception history. "Silence, absence and vacancy" also characterize for Wall the speaker's construction of her own subjectivity. At the heart of Wall's theories of a rent and vacant female subjectivity in Wroth's sonnets is the direction of the subject's gaze. By refusing to blazon the male beloved's body, or to construct him as the mirrored surface of the speaker's own self-regard according to male-authored Petrarchan convention, the subject is seen as withdrawing completely from the public aspects of the Petrarchan tradition - "Wroth seems to expel almost completely the realm of the visible and public world" (pp. $33 \mathrm{I}-38$ ).

Waller's account of Wroth's sequence returns to the same question of 
the woman subject's appropriation of the male Petrarchan subject's lines of sight. Central to his thesis of women's struggle into discourse in the period is that their culturally inscribed positioning as the object of the male subject's gaze problematizes their reversed occupation of the male subject position to such an extent that "in fact it institutionalizes a wholesale gagging of women readers and writers."

At times Pamphilia is "molested" by her role as an object of the desiring gaze; at others she tries to escape the gaze of lover and other people's, in loneliness, isolation or sleep. Such reactions are attempts to avoid the repetitive constructing of sexual relations by patterns of male desire and domination and female submission. In such relationships the values of the patriarchal male predominate: they emerge as the urge to overwhelm, penetrate, defeat and triumph over (p.196).

Against this overwhelming and pervasive male presence, an apt reinforcement of Wall's theories of an absent and vacant female subjectivity, Waller locates one sonnet as a counter-example of Pamphilia's appropriation of the pleasure and power of the male gaze- "Take heed mine eyes, how you your lookes do cast." He also analyzes the sonnet in terms of "the fantasy of emulation," but it remains for Waller a moment in which "Wroth's poems record the stirrings-against enormous odds, it needs to be stressed-to establish an equivalent female subject position," one of the "points of strain and contradiction where alternatives are struggling to emerge" (pp. 19I-219). The identification of the sequence as an excursion into interiority, and thus as a private text, represents an increasingly consistent approach toward Pamphilia to Amphilanthus, informing Kim Walker's recent rejection of Elaine Beilin's "spiritual" reading of the sonnets in favor of their representation of the gendered speaker's "conflicted subject position" (pp. 188-90). Earlier critics showed some concern for the text's operation in the public domain; however, the narrative of gendered suppression which has become the dominant critical approach to the sequence excludes Wroth from such mechanisms. ${ }^{13}$ They focus instead upon the text's interiority and textual strategies of enclosure as a gendered intervention into the genre that is defined as different and feminized by its "private" status.

Both Wall and Waller construe sonnet sequences as monolithic and

13. For analyses of the sequence either preceding Roberts' account of its suppression or emphasizing a public dimension to the text, see Elaine V. Beilin, “' The Onely Perfect Vertue': Constancy in Mary Wroth's Pamphilia to Amphilanthus," Spenser Studies 2 (1981), 229-45; Paulissen, pp. 13 I, 133; Naomi J. Miller, "Rewriting Lyric Fictions: The Role of the Lady in Lady Mary Wroth's Pamphilia to Amphilanthus," in The Renaissance Englishwoman in Print: Counterbalancing the Canon, ed. Anne M. Haselkorn and Betty S. Travitsky (Amherst, Mass., 1990), pp. 295-310. 


\section{Rosalind Smith}

male-coded structures which allow a female subjectivity to be constructed only in terms of absence or "against enormous odds," because they construct the history of women's lyric agency before Wroth's sequence in terms of absence. In almost all readings of Pamphilia to Amphilanthus critics begin by augmenting the text's value by pointing to its anomalous status and its originality. ${ }^{14}$ Yet a Jacobean poet such as Wroth is participating in a genre that is not everywhere coded as male, and in a wider lyric tradition offering a range of precedents for women's construction of a specifically female subjectivity. Although the history of sonnet sequences attributed to women and adopting strategies for the construction of a female subjectivity is far from a coherent or widely available one, its existence suggests that women's participation in secular or male-coded genres was not as difficult as has been assumed. Anne Lok's publication of a sonnet sequence in I560 paraphrasing Psalm SI was followed by two sonnet sequences published under feminine signatures. ${ }^{15}$ Possibly the most widely circulated sonnet sequence in the sixteenth century was attributed to Mary Stuart and published in George Buchanan's Ane Detectioun of the duinges of Marie Quene of Scottes in I 57 I: the Detectioun was reprinted several times in the sixteenth and seventeenth centuries. ${ }^{16}$ In 1584 , John Soowthern's Pandora included a sonnet sequence attributed in the text to Anne Cecil de Vere, Countess of Oxford. ${ }^{17}$ Although these texts are beset by problems of attribution and display a high level of generic mixing, they were read by at least some sections of their audiences as sonnet sequences written by women.

By $162 \mathrm{I}$, Mary Wroth also had available to her a wide tradition of women's secular writing of lyrics and texts which present precedents for the construction of the female speaker or subject. The widespread circulation in print of sonnet sequences attributed to Mary Stuart was supplemented by Elizabeth I's Petrarchan poetry, circulated in manuscript and print, the Continental tradition of women's sonnet writing, and a

14. Beilin claims Wroth adopted the conventions of the Elizabethan sonnet sequence of the 1590 , "yet she radically changed the tradition by making her sonnetteer a woman" (p. 232). Roberts suggests that "chrough the creation of a female persona, she was the first English writer to reverse the sexual roles within a complete sonnet collection" (p. $\left.4^{8}\right)$. Waller identifies it as "the first collection of Petrarchan love poetry in English by a woman" (p. 191).

I s. A|nne] L[ok], Sermons of John Caluin, vpon the songe that Ezechias made after he had bene sicke, and afflicted by the hand of God, conteyned in the 38. Chapiter of Esay (1560).

16. George Buchanan, Ane Detectioun of the duinges of Marie Quene of Scottes (I57I). The I57I English version of the text was released in two issues, probably from the press of John Daye, and was followed in 1572 by a Scottish edition from the press of Robert Lekprevik; a third French edition was published at La Rochelle, although the text gives the place of publication as Edinburgh. See lan McFarlane, Buchanan (London, 1981), pp. 348-50.

17. John Soowthern, Pandora, the Musyque of the Beautie, of his Mistresse Diana (1584). 
tradition of the complaints written by men and women. While the Petrarchan lyric, the sonnet sequence, and the complaint were all genres which, when viewed as exclusively male-authored traditions, encoded specific gender ideologies that problematized the woman author's direct assumption of their speaking positions, they were also all genres appropriated by the woman subject using a variety of strategies more complex than Wall's direct, imitative "transvestitism." As Heather Dubrow has argued, the relationship of gender and genre has produced oversimplifications, producing monolithic female versions of genres that belie the complexity of women's local textual practice. ${ }^{18}$

Wroth's awareness of an existing history of female lyric subjects is borne out by the direct associations which the Urania draws between the female subject of Pamphila to Amphilanthus and Elizabeth I. As Elaine Beilin has observed, the second book of the Urania presents Pamphilia as married by her father to the state in a move which precludes all other suitors, clearly linking Pamphilia with Elizabeth's rhetoric of marriage to her kingdom. ${ }^{19}$ Elizabeth and Pamphilia are also female Petrarchan poets, a connection which locates in Elizabeth's textual agency a site of precedent and agency open to later women poets seeking to write using secular genres. However, the correspondences between them are not direct. Pamphilia's Petrarchan performance far exceeds Elizabeth's, and the Urania's status as a Jacobean text written by an increasingly marginal figure within that court means that it is inflected with a set of discourses which distinctly separate it from Elizabeth's textual practice. The generic choice of the Elizabethan sonnet sequence in this Jacobean context carries with it a specific and distinct set of meanings, one of which is that the sequence formally inscribes a nostalgia for the Elizabethan period while reinforcing the speaker's own withdrawal from the court of her time. Rather than an expression of a private rejection of the courtly life in general, a withdrawal into interiority within the bounds of a genre specifically coded to another period implies a pointed and public rejection of the present court in favor of that period. In Poem 26, "When every one to pleasing pastime hies," repeatedly cited in critical accounts of withdrawal and exclusion from Petrarchan discourse, the speaker sets herself apart from the typical pastimes of the Jacobean court. But the sonnet also politicizes that with-

18. Heather Dubrow, Echoes of Desire: English Petrarchism and its Counterdiscourses (Ithaca, 1995), pp. 147-48.

19. "his Maiestie had once married her before which was to the kingdome of Pamphilia, from which Husband shee could not bee diuorced, nor euer would haue other, if it might please him to giue her leave, to enjoy that happinesse" (p. 228). 


\section{Rosalind Smith}

drawal: the speaker critically represents court pastimes as "voyd of right," "poore vanities" when contrasted with "true pleasure" (p. 100). Through genre Wroth capitalizes upon a cultural nostalgia for the "golden age" of Elizabethan rule and uses the discourses of withdrawal and banishment to express a disenfranchisement from Jacobean rule. The text also positions itself with reference to the past at levels beyond its generic unfashionability, through specific references to courtly events, such as the Masque of Blackness performed in 1608 , and embedded references to its place in a Sidneian textual tradition inseparable from a contemporary Protestant religious and political agenda advocated by the radical Spenserians.

\section{III}

Although the sequence opens with an emphasis on night, blackness, and withdrawal, the first section of the sequence concludes by stressing display, the speaker's grief transformed into "this stage of woe." This increasing resistance to interiority culminates in the final sonnet of the first section, marked off by the signature Pamphilia, in which the burning heart enclosed within the speaker's breast in the opening sonnet becomes a generative force of display, almost consuming the interior subject:

How like a fire doth love increase in mee,

The longer that itt lasts, the stronger still,

The greater purer, brighter, and doth fill

Noe eye with wunder more, then hopes still bee

Bred in my brest, when fires of love are free

To use that part to theyr best pleasing will,

And now impossible itt is to kill

The heat soe great wher Love his strength doth see.

Mine eyes can scarce sustaine the flames my hart

Doth trust in them my passions to impart,

And languishingly strive to show my love;

My breath nott able is to breathe least part

Of that increasing fuell of my smart;

Yett love I will till I butt ashes prove. $\left(\mathrm{P}_{55}\right)^{20}$

The sonnet sets up an anti-blazon of the speakers's own body-"my brest," "Mine eyes," "my breath"-increasingly subsumed by the force of love. But even this physical consumption is recruited to support the

20. Roberts, pp. 114-15. All future references to Pamphilia to Amphilanthus adopt Josephine Roberts' numbering of the poems. 
speaker's display of an exemplary constancy: "Yett love I will till I butt ashes prove." This dynamic of consumption and renewal, coupled with imagery of fire and ash, and a final assertion of the survival of a textual identity in the face of change or death, all recall the phoenix imagery surrounding Philip and Mary Sidney in the I 590 os.

This image, also associated with Elizabeth I, was used by Philip Sidney in Astrophil and Stella, and became increasingly associated with Sidney after his death as an image of his enduring status as poet and Protestant icon, transcending his physical death. Mary Sidney uses the image herself in "To the Angell spirit of the most excellent Sir Philip Sidney," the second of two dedicatory poems to her brother prefacing the edition of the psalms which she completed after his death: "Phoenix thou wert, so rare thy fairest minde." 21 The poem later depicts him in heaven with the privileged position of singing "thy Makers praise," implying a proximity to God for both its psalmist and the Protestantism he advocated, and promoting his existing works in an increasingly hostile environment at court: "as here thy workes so worthilie enbrac't / By all of worth, where never Envie bites" (p. 93). However, largely because of her role in continuing to promote her brother and the Protestant cause at court, the image of the phoenix also began to be attached to Mary Sidney. As Margaret Hannay has argued, other contemporary constructions of Mary Sidney represent her as embodying her brother's spirit without the use of the phoenix image, but with reference to the ideas of renewal after death which underpin phoenix typology. ${ }^{22}$ Through its phoenix imagery, the Urania sequence may be signalling a specific connection with a political, Elizabethan and Sidneian tradition which positions Wroth as a successor to Mary Sidney, who died the year of the Urania's publication. The name of the text itself suggests this connection. Spenser, who initiated the formulation of Philip Sidney as ideal Protestant writer and courtier and Mary Sidney as his successor in a dedicatory sonnet in the Faerie Queene, repeats this construction in Colin Clouts Come Home Again, figuring Philip Sidney as Astrophil and Mary Sidney as Astrophil's sister Urania, the muse of Christian poetry. ${ }^{23}$ Because of her gender, Mary Sidney's assumption of the identity of Philip's phoenix is peculiarly open to a second

21. The Triumph of Death and Other Unpublished and Uncollected Poems by Mary Sidney, Countess of Pembroke, (1 s61-1621), ed. G. F. Waller (Salzburg, 1977), p. 93.

22. Margaret Hannay, Philip's Phoenix (Oxford, 1990), p. 82.

23. The Works of Edmund Spenser: The Minor Poems, ed. Edwin Greenlaw et al., 2 vols. (Baltimore, 1943), I, I61. 


\section{Rosalind Smith}

identification as Urania, an identity in which she received a number of dedications of devotional works. The text's title, apparently privileging a relatively marginal figure in the romance over its central protagonist Pamphilia, registers in this displacement a positioning of the text as part of this gendered Protestant tradition centered around Mary Sidney.

The prose text of the Urania contains an epitaph to the lady Myra, an anagram of Mary, which also uses the phoenix imagery associated with Mary Sidney; it places a religious gloss upon the conventional praise of her virtues by including faith among them, and by representing her death as the will of Heaven:

Egypts Pyramids inclose their Kings,

But this farr braver, nobler things;

Vertue, Beauty, Love, Faith, all heere lye

Kept in Myras Tombe, shut from eye:

The Phoenix dyes to raise another faire,

Borne of her ashes, to be heire;

So this sweete Place may claime that right in woe,

Since heere she lyes, Heaven willing so. $(448)^{24}$

Importantly, this poem feminizes its image of the phoenix and her successor, "another faire, / Borne of her ashes," in contrast to the representation of the myth in The Metamorphoses:

Then from his father's body is reborn

A little Phoenix, so they say, to live

The same long years. When time has built his strength

With power to raise the wight, he lifts the nest-

The nest his cradle and his father's tomb-

As love and duty prompt, from that tall palm

And carries it across the sky to reach

The Sun's great city, and before the doors

Of the Sun's holy temple lays it down. ${ }^{25}$

In a Jacobean context, where the iconography of the sun was associated with James in the same way as that of the moon had been with Elizabeth,

24. Roberts, p. 180. Margaret Hannay also suggests that the Queen of Naples might be associated with Mary Sidney, as does Josephine Roberts in her edition of the prose text of the Urania. Margaret P. Hannay, "Your vertuous and learned Aunt': The Countess of Pembroke as a Mentor to Mary Wroth," in Miller and Waller, Reading Mary Wroth, pp. 25-30; Lady Mary Wroth, The first part of The Countess of Montgomery's Urania, ed. Josephine Roberts (Binghamton, NY, 1995), pp. Ixxxiv-lxxv.

25. Ovid, Metamorphoses, trans. A.D. Melville (Oxford, 1986), pp. 363-66. 
another element of the phoenix myth takes on a new significance: the phoenix's duty to offer her predecessor's legacy to the king.

For Wroth, positioned through Pamphilia and the epigraph to Myra as the phoenix-like inheritrix of Mary Sidney, that legacy is a history of Protestant activism within the court, expressed either through the publication of texts designed to promote the Protestant cause or through the related project of sustaining the myth of Philip Sidney as Protestant hero. ${ }^{26}$ The year of the Urania's publication, 1621, marked a period of crisis in James's reign centered on his cautious, non-interventionist policy in Europe and a resurgence of Protestant activism in the Jacobean court in support of the Princess Elizabeth and the Continental Protestant cause. The major textual proponents of the Protestant position in this crisis were the group of poets identified as Spenserian by their shared defense of the public, instructive role of poetry and the prophetic independence of the poet against what was seen to be the hostile culture of the Jacobean court. Although the group was not always ideologically coherent, they generally supported a Protestant religious agenda that found literary expression in the characterization of Elizabeth's reign as a lost golden world which embodied the Protestant ideals perceived to be absent from the Jacobean courts. ${ }^{27}$ An earlier crisis in the English court in $1613-1614$, when an imminent war on the Continent again aroused Protestant fears that the Jacobean court was dominated by pro-Spanish factions, led to the first consistent formulations of this nostalgia in the form of pastoral poetry by a group which loosely included William Browne, Christopher Brooke, Samuel Daniel, John Davies, Michael Drayton, Giles and Phineas Fletcher, Fulke Greville, Joshua Sylvester, and George Wither. ${ }^{28}$ They in turn identified themselves with a group of aristocratic Protestant patrons per-

26. Mary Wroth's relationship with her cousin William Herbert could be related to this project of keeping the Sidneian tradition alive. Hannay notes that an important early text in the construction of Philip Sidney as martyr for the Protestant cause, Thomas Moffett's Nobilis (1593), was presented to Herbert as a New Year's gift, and presents Philip Sidney's life as a template for Herbert's own: "Therefore do you embrace, cherish, and imitate him, your second self" (pp. 80-8I). If Herbert is to be viewed in these terms, then another aspect of Wroth's inheritance of the role of Mary Sidney could lie in her promotion of Philip Sidney through his replacement, Herbert, paralleling Mary Sidney's revival of her brother's name and reputation. However, this interpretation is problematized by the ambivalent representation of the figure of Amphilanthus, to whom one of Herbert's poems is attributed, in the Urania. In Tudor and Stuart Women Writers (Bloomington, Ind., 1994), Louise Schleiner considers Wroth's ambivalent representation of Pembroke as Amphilanthus in the Urania, and argues that she is retrospectively presenting her relationship with Pembroke in sanitized terms against court gossip (pp. 156-63). See also Roberts, Urania, pp. xlv-xlvii.

27. David Norbrook, Poetry and Politics in the English Renaissance (New York, 1984), pp. 207, 216-2I.

28. Norbrook, Poetry and Politics, pp. 197-99. 


\section{Rosalind Smith}

ceived to be independent of courtly corruption and intrigue, often identified in terms of a physical withdrawal from the court to the country, who included a distinct group of women courtiers: Susan Herbert, Countess of Montgomery; Lucy Harington, the Countess of Bedford; and Lady Mary Wroth.

\section{IV}

Wroth was the object of a set of Spenserian dedications. The most populist and politically inflammatory of the Spenserians was George Wither, who included Wroth among the other Protestant patrons to whom he dedicated his 1613 satire Abuses Stript and Whipt, distinguishing his conventional praise of her virtues by associating them with "true unfained Vertues" and identifying her as an active patron of the arts. ${ }^{29}$ The text contained thinly disguised attacks on corruption in the court, and its inflammatory content resulted in Wither's imprisonment in I6I4. Two less controversial Protestant poets dedicated texts to Wroth during this period: Joshua Sylvester in Lachrimae Lachrimarum (1612) and George Chapman in his translation of the Twelve Bookes of the Iliads (1609). In sharp contrast to the conventional sonnet to the Countess of Montgomery's virtue in the same volume, Chapman's sonnet to Wroth positions her as a new star "Discouered in our Sydneian Asterisme," an advocate of a "true Reason, and Religion" in opposition to "the times Apostasie," and pursuing a separate path from her corrupt contemporaries: "Then shun their course, faire Starre; / And still keepe your way, pure, and circular." ${ }^{30}$ Sylvester's dedicatory sonnet presents Wroth in the same Sidneian terms, as "Sidniëdes / In whom, her Uncle's noble Veine renewes." 31 The year of the Urania's publication marked a resurgence of this group of writers in response to the new crisis on the Continent. In 1621 , George Wither published, and was again imprisoned for, his satire Wither's Motto. The second part of Drayton's Poly-Olbion, published in I622, contains a panegyric to Ralegh, an important figure in the Protestant "golden age," who was executed in 1618 as part of James's policies of appeasement with Spain. In the years preceding 1620 , Mary Wroth's literary status as a

29. Wither, Abuses Stript and Whipt (16 13 ).

30. The Poems of George Chapman, ed. Phyllis Brooks Bartlett (New York and London, 1941), p. 400. As a contrast to this Protestant construction of Mary Wroth, the sonnet to Susan Herbert refers briefly to a more generalized fame and virtue, but deals largely with poetic rivalry and potential patronage.

31. Joshuah Sylvester, The Complete Works of Joshuah Sylvester, ed. Alexander B. Grosart, 2 vols. (1880), 11, 282 . 
patron of this group was reactivated through the publication of a number of collected editions of their work, editions all reproducing the earlier dedications, which position Wroth as a Sidneian, Protestant patron. ${ }^{32}$ Although Wroth was increasingly less involved with the court, her retirement was not absolute; diaries and letters indicate that she was still active in the Sidney and Herbert circles that formed a locus of support for Protestant politics. ${ }^{33}$ The Countess of Montgomery was herself a Protestant patron: Robert Newton's short Protestant prose tract, The Countess of Mountgomeries Evsebeia, was dedicated to her in 1620 , and Donne accompanied a sermon which she had requested with a letter which makes their relationship of patron and client clear. ${ }^{34}$ However, the dedications made separately to Susan Herbert and Mary Wroth are quite different: those addressed to the Countess of Montgomery position her as a patron to a general body of Protestant writers, but those addressed to Wroth issue from a more specific, marginal, and oppositional body of Spenserian writers.

This connection of Wroth with the Spenserians is reinforced by the use of John Grismand and John Marriott as the Urania's publishers, and Augustine Mathewes as its printer. The Spenserian poets consistently used this combination of printer and publisher. ${ }^{35}$ They were also a printer and publisher implicated in the marginal and radical status of the texts which they produced-in I62I they were fined for printing Wither's Motto without a license. Their questionable reputation has usually been taken as evidence for the Urania's publication without Wroth's permission. ${ }^{36}$ However, Wroth's use of the typology associated with Mary Sidney, Urania, and the feminized phoenix, as well as her patronage of the group of Spenserian poets also concerned with the textual continuation of an idealized, Elizabethan Protestantism within which Mary and Philip Sidney were central figures, suggests that the text's publishers and printer

32. Jonson's Works and George Chapman's collection of the works of Homer were published in 1616 , Joshua Sylvester's collected works in $1620 / 21$, and George Wither's collected works were published under the title Juvenilia in 1622 .

33. Roberts, p. 27.

34. Robert Newton, The Countess of Mountgomeries Evsebeia (1620), and John Donne, Letters to Several Persons of Honour ( $165 \mathrm{I}$ ), p. 26.

35. John Grismand and John Marriot jointly published, with Augustine Mathewes as printer, Michael Drayton's Poly-Olbion, Part I (1622) and Part 2 (1622), and George Wither, Wither's Motto (1621) and Faire-Virtue (1622). Individually, John Grismand published Wither's Emblems (1635) with Augustine Mathewes as printer; independently of Mathewes, Grismand also published Wither's Britain's Remembrancer ( 1628 ) and Juvenilia (1633); and John Marriot published Davies' Overburies wife (1616). Michelle O'Callaghan, "Three Jacobean Spenserians: William Browne, George Wither, and Christopher Brooke," diss., University of Oxford, 1993, 344.

36. See Margaret Anne Witten-Hannah, "Lady Mary Wroth's Urania: The Work and the Tradition," diss., University of Auckland, 1978, 66-107; Roberts, p. 70. 
might reflect its own political position as a part of this group of Spenserian texts.

Wroth's alignment with the radical Spenserian poets is qualified by the constant tension constructed in the sequence between the private and public spheres. In Pamphilia to Amphilanthus, Poem 40 centers around an analogy drawn between false hope in love and the false rule of tyrants (p. 107). The speaker's private experience works as a point of entry into a commentary upon the political practice of capricious favoritism by an absolutist ruler:

Faulce hope which feeds butt to destroy, and spill

What itt first breeds; unaturall to the birth

Of thine owne wombe; conceaving butt to kill,

And plenty gives to make the greater dearth,

Soe Tirants doe who faulsly ruling earth

Outwardly grace them, and with profitts fill

Advance those who appointed are to death

To make theyr greater falle to please theyr will.

Thus shadow they theyr wicked vile intent

Coulering evill with a show of good

While in faire showes theyr malice soe is spent;

Hope kills the hart, and tirants shed the blood.

For hope deluding brings us to the pride

Of our desires the farder downe to slide.

Although it is difficult to characterize such a sonnet in terms of a gendered refusal of the public sphere, the register of the speaker's engagement with the political is muted in comparison with some male-authored sequences of the period. The politics of the sequence align more closely with the ambivalence toward courtly life associated with Tacitism, a movement closely aligned with Wroth's father, Robert Sidney. A library catalogue and a set of commonplace books kept by Robert Sidney and passed to the second Earl reveal the family interest in writers within a Machiavellian tradition, containing works by Polybius, Livy, Tacitus and Machiavelli, as do their contacts with figures concerned with the translation of Tacitean texts and the dissemination of Tacitean political thought. ${ }^{37}$ While part of the Sidney circle of coterie readers, a writer such as Fulke Greville expresses his disaffection with the court in more explicit

37. Blair Worden, "Classical Republicanism and the Puritan Revolution," in History and Imagination: Essays in honour of H.R. Trevor-Roper, ed. Hugh Lloyd-Jones, Valerie Pearl and Blair Worden (London, 1981), pp. 187-88. 
and personalized terms. The sequence Caelica closes with a poem identifying the sovereign as the incarnation of "Impiety," and contains in sonnets 77 to 83 a set of political poems dealing with the abuse of power by "our moderne Tyrants." Sonnet 83 analyzes the recurrent themes of the rise of court favorites and the speaker's exclusion from favor in typically explicit terms:

Like as the Kings forlorne, depos'd from their estate,

Yet cannot choose but loue the Crowne, although new Kings they hate;

If they doe plead their right, nay, if they onely liue,

Offences to the Crowne alike their Good and Ill shall giue;

So (I would I were not) because I may complaine,

And cannot choose but loue my Wrongs, and ioy to Wish in vaine;

This faith condemneth me, my right doth rumor moue,

I may not know the cause I fell, nor yet without cause loue. ${ }^{38}$

A similar analysis of the subject's resistant relationship to tyrannical power occurs in Poem 8 of Pamphilia to Amphilanthus, but couched in the terms of courtly love in a mocking address to Cupid, concluding "Yett this Sir God, your boyship I dispise; / Your charmes I obay, butt love nott want of eyes" (p. 9o). The difference in register and force of critique between the texts by Wroth and Greville suggests that Pamphilia to Amphilanthus should not be placed too emphatically in the public sphere. The focus of the sequence upon love, and its consistent use of erotic diction and metaphor, comparatively dilutes its political engagement by embedding its criticism in erotic discourse. This strategy of moderation may be genderdriven, but it may also qualify the text's radical Spenserian stance toward the court with the mixed attraction and criticism of Sidneian Tacitism.

The sonnet "Like to the Indians, scorched with the sunne" exemplifies this political ambivalence, centred upon contemporary associations of the typology of the sun with James:

Like to the Indians, scorched with the sunne,

The sunn which they doe as theyr God adore

So ame I us'd by love, for ever more

I worship him, less favors have I wunn,

Better are they who thus to blacknes runn, And soe can only whitenes want deplore

38. Poems and Dramas of Fulke Greville, ed. Geoffrey Bullough. 2 vols. (Edinburgh and London, [938), I, 133 . 


\section{Rosalind Smith}

Then I who pale, and white ame with griefs store,

Nor can have hope, butt to see hopes undunn;

Beesids theyr sacrifies receavd's in sight

Of theyr chose sainte: Mine hid as worthles rite;

Grant mee to see wher I my offrings give,

Then lett mee weare the marke of Cupids might

In hart as they in skin of Phoebus light

Nott ceasing offrings to love while I Live. (P25)

The poem reactivates the imagery of the Masque of Blackness to make this a text less about erotic love than about methods of worship and their operation in the Jacobean court. Jonson wrote the Masque of Blackness, in which Mary Wroth performed, but its thematic material, and specifically the identification of the masquers with the daughters of Ethiop, were incorporated at Queen Anne's request. The masque oscillates between a representation of blackness as beautiful in its own right, a reflection of the sun's "fervent'st love," and its representation as alien and inferior when seeking incorporation into the fair Britannia. ${ }^{39}$ As Hardin Aasand argues, it concludes with a troubling ambiguity. The daughters of Niger are neither made literally fair through the sun's favor nor fair through a redefinition of the value of their blackness, which makes ambiguous the power attributed to James and the success of his policies of union in including the other within the rhetoric of nationhood. ${ }^{40}$ But it also leaves Anne, as gendered poet and performer, in a position of marginalization, which in 1608 was registered through her ethnic and religious difference: a construction of both sovereigns, which provides a model for Wroth's reworking of the masque in this sonnet in a new political context.

As Anne had done, the speaker identifies herself with the Indians, "scorched with the sunne, / The sunn which they doe as theyr God adore," in a process which defines them as marked and damaged by their religious practice. But the associations of this sonnet with the imagery of the Masque of Blackness means that, for the speaker, the punishing sun is identified with James rather than a religious God, a figuration then altered to Cupid or love, while repeating the theme of disenfranchisement from favor through worship- "for ever more / I worship him, less favors have I wunn." In the second quatrain, however, the sonnet presents a

39. Ben Jonson, ed. C.H. Herford and Percy and Evelyn Simpson, il vols. (Oxford, 1941), VIl, $161-80$.

40. Hardin Aasand, " 'To blanch an Ethiop, and revive a corse': Queen Anne and The Masque of Blackness," Studies in English Literature 32 (1992), 282-83. 
more traditional alignment of blackness with others- "they who thus to blacknes runn"-against whom the speaker seeks to define herself, here again in terms of an exclusion from the sun: "I who pale, and white ame with griefs store." As Kim Hall argues, associations in literature of the period between blackness and paganism were available to Protestant antiCatholic rhetoric. ${ }^{41}$ Wroth's sonnet aligns itself with this typology by setting up in the sestet a distinction between those whose "sacrifies" is received "in sight / Of theyr chose sainte," and the speaker, for whom religious display must remain "hid as worthles rite." Ultimately, religious belief is redefined as internal and private, "in hart," in keeping with Protestant doctrine.

Yet at points the sonnet seems to resist this model of Protestantism; the speaker, like the Indians with whom she at first identifies, harbors a residual desire to make offerings even as she defines herself against those who may do so. It produces a sense of caution, a wariness against a selfpositioning in radical opposition either to "they in skin of Phoebus light" or to Phoebus himself, which is consistent with the sonnet's cautious embedding of its religious complaint within an erotic discourse. The same ambivalence toward James's power concludes the Masque of Blackness, and is mobilized here through exactly this convergence of erotic and religious themes. According to contemporary representations of James as Solomon, his relationship with the dark and comely bride enlarges to become the exemplar of Christ's love refracted through the divinely elected king: "she becomes fair through God's favour." ${ }^{2}$ However, this association of James and Solomon also carried the negative connotations of an excessive corporeal sensuality, coupled with Protestant fears of an unrecuperated foreign woman in the English court centered upon the marriage negotiations between Prince Charles and the Spanish Infanta. Thus the speaker posits her fairness first in terms of separation, then in terms of identification with the "marke of Cupids might / In hart," implying in these constructions that the power invested in God's representative on earth has been wrongly directed. But the equivalence of her own internal marking with the ambiguous image of a "skin of Phoebus light," either dark like the Indians or made light through reference to the

41. Kim Hall, Things of Darkness: Economies of Race and Gender in Early Modem England (Ithaca, 1995), pp. 103-05.

42. Hall, p. I Io. Kim Hall's reading of this poem, however, follows the critical emphasis upon women's lack of poetic agency and textual confinement to the private sphere, arguing that the subject's hidden "sacrifices" are her poems, "private art" which go unrecognized, "while male poets can speak publicly of their loves and circulate their "sacrifices" or poems (106-07). 


\section{Rosalind Smith}

Song of Songs, leaves open the potential for the sovereign's right exercise of power, operating in concordance with the speaker's religious agenda.

The gender of the speaker and beloved in this sequence operates in the opposite configuration to private enclosure; it enables an attribution to the male figure of the beloved of a range of different subject positions which register his mobility and multi-valency in the Jacobean court, and allows the sequence to address more than the private relationship of poet and idealized beloved. As Montrose and others have shown, the same new aspects of the genre were taken up in the Elizabethan court through the placement of Elizabeth as sonnet-mistress. Wroth's use of the genre in the Jacobean period, with its cultivated nostalgia for an Elizabethan "golden age," capitalizes upon the same availability of the male sovereign to be positioned with the beloved in a bid for a particularized kind of royal favor and a complaint against its denial. The shifting associations of James, Phoebus, Cupid and the speaker's beloved in "Like to the Indians, scorched with the sunne" provide a template for the construction of the male beloved throughout the sequence, and is shown most clearly in Wroth's constant references to the Court of Love and the Anacreontic Cupid. ${ }^{43}$

The political value of these shifting conceptions of the male beloved becomes clear in one discrete group of sonnets: the frequently anthologized corona in the second section of the sequence, which associates the power of bestowing sovereignty with the poet rather than with the divinely elected sovereign. The court represented in this group of poems is a utopian vision of a place where a right love is valorized in religious terms:

Love is the shining starr of blessings light;

The fervent fire of zeale, the roote of peace,

The lasting lampe fed with the oyle of right;

Image of fayth, and wombe for joyes increase. $\left(\mathrm{P}_{78}\right)$

It is presided over by a monarch of light, untouched by "staine" or "spott," whose rule is characterized by fairness, justice, truth and constancy:

Please him, and serve him, glory in his might,

And firme hee'll bee, as innosencye white,

43. Heather Dubrow also comments upon Wroth's shifting constructions of Cupid, but attributes this to the multiple roles played by the female subject, and Wroth's own "projecting onto her mythological characters the multiple and often contradictory roles she herself assumes" (pp. 158-59). 
Cleere as th'ayre, warme as sunn beames, as day light, Just as truthe, constant as fate, joy'd to requite,

Then love obay, strive to observe his might,

And bee in his brave court a glorious light. (P79)

This ideal court provides a new frame of reference for the speaker's selfcharacterization. She juxtaposes the phoenix-like body, consumed by and emitting light, against a vision of Revelation in the fourth sonnet of the corona:

Never to slack till earth noe stars can see,

Till Sunn, and Moone doe leave to us dark night,

And secound Chaose once againe doe free

Us, and the world from all devisions spite ${ }^{44}$

But until then, the burning of love becomes a way for the faithful to abolish sin and fear and to replace them "with vertues which inspire / Soules with devine love, which showes his chaste love" (P8I). Wroth's imagery reflects the Protestant shift to a belief in the imminence of the apocalypse as Thomas Brightman suggested in 1650; John Harrison, whose edition of The Messiah Already Come was first published in 1613 , proposed a date as close as $1630 .{ }^{45}$ Indeed, many radical Protestant texts express a concern with the apocalypse, figured in part through the female figure of Aletheia, the representation of apocalyptic truth. In Browne's Britannia's Pastorals, she is represented as wandering in exile, much like Wroth's Pamphilia, although in Browne's text that exile is characterized in terms of specific sites of abbey, court and town rather than Wroth's less material space of erotic absence and exclusion. ${ }^{46} \mathrm{~A}$ draft of an unperformed masque celebrating the Palatine match used Aletheia as its central figure as part of an apocalyptic vision of a final, international reunion of Protestants; the muses sing before her a song promoting the union of sovereigns following the model of the English king, under whom foreign religions are subordinated to the true religion. ${ }^{47}$ Although the Protestant agenda of Wroth's text is less overt and is directed to a model of right government within the English court rather than to an internationalist vision, the speaker is

44. P. 80. See Revelations 6.12: "And I behelde when he had opened the sixt seale, and lo, there was a great earthquake, \& the sunne was as blacke as sackecloth of heere, and the moone was like blood."

45. David Norbrook, "'The Masque of 'Truth': Court Entertainments and International Protestant Politics in the Early Stuart Period," The Seventeenth Century 1 (1986), 90.

46. William Browne, Britannia's Pastorals (1616), pp. 73-109.

47. Norbrook, "The Masque of Truth," pp. 104-05. 


\section{Rosalind Smith}

taking up the Spenserian vision of Aletheia as exile, the source of purging flame, and the embodiment of truth in the face of apocalypse.

The apocalyptic imagery in Wroth's text is ostensibly identified with Cupid, yet through an overtly biblical frame which offers a model of right government in a fictional court. The focus of the corona of sonnets shifts to present the consequences for a male subject who fails to construct himself in these terms: "Hee that shunns love doth love him self the less / And cursed hee whos spiritt nott admires / The worth of love" (P84). "He," now specifically Cupid, is replaced in P85 in the context of the court of his mother, Venus, which is represented as the antitype of the utopian court which the speaker has envisaged under her son, a place of "follyes" and "stile of love who hath lasiviouse bin." It recalls the troubled Scottish court of James's own mother, and provides an admonitory counter example to the idealized court which the speaker constructs for the "Great King of Love" as his servant. Any implicit criticism of a Jacobean court "imbrasing looce desires, and wanton play" (P95), however, is distanced by its displacement onto a feminized frame.

The tension between the ideal and its opposite, still abstracted to the level of the Court of Love, finds a less mythological focus in the final sonnet of the corona. In this poem the speaker represents both her gift of the crown of a court characterized in divine terms, and her self as rejected and undervalued servant. The pun on "worthles" suggests that the court of envy and jealousy in which this occurs resembles that of her own Jacobean experience:

Except my hart which you beestow'd before, And for a signe of conquest gave away As worthles to bee kept in your choyse store Yett one more spotles with you doth nott stay.

The tribute which my hart doth truly pay

Is faith untouch'd, pure thoughts discharge the score

Of debts for mee, wher constancy bears sway,

And rules as Lord, unharm'd by envyes sore,

Yett other mischiefs faile nott to attend, As enimies to you, my foes must bee; Curst jealousie doth all her forces bend To my undoing; thus my harmes I see.

Soe though in Love I fervently doe burne, In this strange labourinth how shall I turne? ( $\left.\mathrm{P}_{90}\right)$ 
The corona finishes by transforming the speaker's self-construction as representative of an idealized Protestant court ruled by a godly king into a bid for personal favor and a complaint against her exclusion through the forces of "Curst jealousie." As Ann Rosalind Jones has noted, the sonnet has a strong element of local, political self-interest: "As enimies to you, my foes must bee." ${ }^{88}$ However, it is coupled with references to the speaker's earlier self-construction as an embodiment of divine virtue, "in his brave court a glorious light," which enlarges this bid for personal favor to a bid for the institution of her utopian and godly court in a specific Jacobean context-the phoenix offering her Protestant legacy to the king.

The final section of the sequence again places the speaker in exile, "Disdaining light wher Cupid, and the race / Of Lovers are dispisde, and shame shines cleere" (Proo). But her exile is now at one level from a corrupted court in which she has little investment, and at another from an impossible court of her own fictional making, leaving her, as she puns, "bard of my chiefe light" (PIOO), a typically Spenserian exile and divine poet. In a Petrarchan context, a poetic position very different from that of the Elizabethan sonneteers is worked out in these sections of the sequence, clearly expressed in the last sonnet ( $\left.\mathrm{P}_{1} \mathrm{O}_{3}\right)$ :

My muse now hapy, lay thy self to rest,

Sleepe in the quiett of a faithfull love,

Write you noe more, butt lett thes phant'sies move

Some other harts, wake nott to new unrest,

Butt if you study, bee those thoughts adrest

To truth, which shall eternall goodnes prove;

Injoying of true joye, the most, and best,

The endles gaine which never will remove;

Leave the discource of Venus, and her sunn

To young beeginers, and theyr brains inspire

With storys of great love, and from that fire

Gett heat to write the fortunes they have wunn,

And thus leave off, what's past showes you can love,

Now lett your constancy your honor prove,

Pamphilia (PI03)

Conventional erotic Petrarchan poetry is seen as the province of "young beeginers," against the "storys of great love," equivalent in the imagery of

48. Ann Rosalind Jones, "Designing Women: The Self as Spectacle in Mary Wroth and Veronica Franco," in Miller and Waller, pp. I 35-53. 


\section{Rosalind Smith}

the sequence to a divine love, which the speaker has previously positioned herself as writing. Implicitly, her own text is set up as an exemplary model to other writers, renewing the phoenix imagery of self-generating "fire" in a textual as well as a religious context, and transferring the example of Mary Sidney through her own text to a wider audience of "some other harts." It returns Petrarchan erotic discourse from a secular to a religious frame, but in a move itself typically Petrarchan in its promotion of the poet's own work. In a sense, nothing could be further from the withdrawal from circulation advocated by Masten and Wall. Wroth is positioning her sequence in a wide political and religious frame, and in a Protestant literary tradition integrating both Sidneian and radical Spenserian agendas.

The privileging of the private in the criticism of this sequence both ignores Wroth's own political alignment with a group of radical Protestant writers within the Jacobean court, and also reads the sections of the sequence advocating a utopian Protestant court and the speaker's central role in that court only in terms of the private frame implicit in the ambitious Protestant courtier's rhetoric. It allows Barbara Lewalski to argue explicitly that "in claiming the Petrarchan love sequence for the female lover-poet, Wroth did not use it as male courtiers often did, for overt political purposes" (p. 263). Gender does not operate in the sequence by precluding a political purpose, but enables it, by allowing the woman sonneteer to take up the Elizabethan multi-valency surrounding the sovereign as sonnet master/mistress and to transfer it to a Jacobean context and a male sovereign. Wroth's unfashionable circulation of the sonnet sequence as late as $162 \mathrm{I}$ registers more than a disenfranchisement from current courtly fashion in favor of a Spenserian nostalgia for Elizabeth's reign; it actively seeks political, religious, and textual purchase on a range of public and private levels by reworking those tropes in a Jacobean context. 